\title{
Transposition
}

Musique et Sciences Sociales

9| 2021

Musique et sexualité

\section{Retrospective Reflections}

\section{Annegret Fauser}

\section{(2) OpenEdition}

\section{Journals}

\section{Electronic version}

URL: http://journals.openedition.org/transposition/6417

DOI: 10.4000/transposition.6417

ISSN: 2110-6134

\section{Publisher}

CRAL - Centre de recherche sur les arts et le langage

\section{Electronic reference}

Annegret Fauser, "Retrospective Reflections", Transposition [Online], 9 | 2021, Online since 30 March 2021, connection on 23 April 2021. URL: http://journals.openedition.org/transposition/6417 ; DOI: https://doi.org/10.4000/transposition.6417

This text was automatically generated on 23 April 2021.

\section{(c) (†) (?)}

La revue Transposition est mise à disposition selon les termes de la Licence Creative Commons Attribution - Partage dans les Mêmes Conditions 4.0 International. 


\title{
Retrospective Reflections
}

\author{
Annegret Fauser
}

1 It is a historiographical commonplace to say that, in Western music, the "pleasure of the ear" as mentioned in this text's epigraph might be a challenge. From the monk John of Salisbury, who opined in the twelfth century that the new polyphonic music at Notre Dame aroused "titillation between the legs more readily than a sense of devotion in the brain", to the American politician James P. Bradley who, in August 2020, was scandalised by the overt sexuality in "WAP", a hip-hop video by Cardi B and Megan Thee Stallion, testimonies about the sensual, even erotic, dangers of music abound in writings on music even dating as far back as Greek antiquity. Scholarly interest in eroticism in music, however, is much more recent. The present text - written in 1992 for a conference entitled Massenet et son temps ("Massenet and His Time") and published seven years later in the corresponding proceedings - was one of the first musicological essays explicitly to discuss the sonic embodiment of the physical aspects of human sexuality. ${ }^{1}$ My research on this issue dates from thirty years ago, and it was a first step exploring the implications of gender and sexuality in Massenet's operas. Now it can enter into dialogue with a growing number of musicological studies of these issues, not least within the genre of opera.

In rereading this essay, I was struck by the density of the sources consulted so as to construct my analysis. Esclarmonde is a work with an extraordinary wealth of paratexts, even for the late nineteenth century - a period generally characterised by an abundance of reviews and newspaper commentary, interviews and memoires, and iconographical documents including photographs as well as caricatures. The opera's connection to the Paris World's Fair of 1889 only amplified its impact, given what was a stake in signalling the importance of official French art in a context that gave it both national and international visibility. While Esclarmonde definitely fit within the framework of modern opera in terms of its subject, staging, and musical idiom, the work went beyond the confines of bourgeois propriety, theatrical conventions, and musical signification, especially through its use of orchestration. It is within this liminal space that the opera's erotic acoustemology could come to light in an analysis such as mine, one that centred on the musical expression of human experience. ${ }^{2}$ I thought of the opera as constituting an audible archive of the construction of gender 
and sexuality through their erotic expression within a world that was, on the one hand, traditional and patriarchal with regard to its representation of normative binary sexuality, and on the other, transgressive through a music that pushed the envelope of post-Wagnerian decadence. Esclarmonde is a textbook example of the fact that an artwork can be simultaneously oppressive in social terms and avant-garde in style. (Incidentally, Igor Stravinsky's Rite of Spring is perhaps the best-known example of this type of theatrical work).

3 My text was situated within an analytical field informed, on the one hand, by research on Wagnerism in France, and on the other, by the new feminist theories that, around 1990, considered music as a sonic embodiment of human experience. After all, Susan McClary's seminal book, Feminine Endings, was published in 1991. It was at that time that debates in musicology began to articulate issues of sexuality using methodologies framed, inter alia, by post-colonial theory, gender studies, and the concept of vocality. If I were to map out further areas of inquiry today, I would focus on the intersection between eroticism and exoticism, as well as the implications of constructed vocalities in opera.

In my text, I cited Camille Bellaigue's reaction to the title character, describing Esclarmonde as 'that sensual little Turk', ${ }^{3}$ and I briefly referred to Ralph P. Locke's article on the construction of an Orientalist otherness in European opera, using Camille Saint-Saëns's Samson et Dalila as his case study. In the 1990s, however, my attention was more focused on a feminist analysis of sexual representation than on a geopolitical problem. Since then, a significant body of scholarship, including my own, has shown the degree to which the ideological construction of femininity and masculinity in latenineteenth-century Europe was entwined with an imperialist vision of humanity and its cultures. More recent research has highlighted how representations of Others depend on a white and patriarchal conception of Europe. ${ }^{4}$ If my feminist analysis of Esclarmonde were to be expanded through a reading informed by post-colonial theory, I would now offer a more in-depth analysis of the intersections between the opera's different identity constructions, not only in the plot and in the libretto but also in the way in which the composer constructed the characters' vocalities. ${ }^{5}$ In the role of Esclarmonde, for example, the modes of articulation cover an expressive gamut, ranging from silence to laughter and from speaking to coloratura. At first glance, this rich expressive range the broadest of all the characters in the opera - could be seen as a heightened sonic presence, constituting a sense of musical domination on the part of the Other. ${ }^{6}$ But as I show in my essay, this presence is subject to a dual patriarchal constraint and, in the epilogue, is musically framed by an affirmation of Western music. At the end of the opera, all of Esclarmonde's musical and sexual affirmation is but a sonic memory of which only a phantom genealogy remains in her voice. The new empress is dispossessed of any trace of exoticism or eroticism, with her seemingly exotic attributes erased both acoustically and visually. As I have already suggested, were I to delve deeper into the subject, I would explore further how Esclarmonde sonically celebrates a normative heterosexuality, and how this tie into the imperialist construction of white virtue.

Why is it important to examine this opera from 1889 in dialogue with post-colonial theory, especially at this point in time? I am writing these reflections from the Unites States, a country where sexuality, gender, and ethnicity have a tragic intersectional history. ${ }^{7}$ These ideological constructs translate into violence against men and women of 
colour (and Black transgender women in particular), as well as a normative approach to cultural values that deem as abject the musical expressions of feminine sexuality, especially if Black. Understanding how an artwork such as this was showcased in an imperial capital, during a colonialist World's Fair with international reach, can shed light on the long-term impact of the musicalisation of identity issues, including gender and ethnicity. Viewed and listened to in this manner, Esclarmonde becomes a performative archive whose values continue to mould present-day ideologies on the bio-presentations of art and life.

\section{BIBLIOGRAPHY}

BOGHAL Gurminder Kaur, “Lakmé’s Echoing Jewels”, dans cowGILL Rachel et PORISS Hilary (dir.), The Arts of the Prima Donna in the Long Nineteenth Century, New York et Oxford University Press, 2012, p. 186-201.

DUNN Leslie C. et JONES Nancy A. (dir.), Embodied Voices. Representing Female Vocality in Western Culture, Cambridge et New York, Cambridge University Press, 1994.

EIDSHEIM Nina Sun, The Race of Sound. Listening, Timbre, and Vocality in African American Music, Durham, Duke University Press, 2019.

FELD Steven, “Acoustemology”, NOVAK David et SAKAKEENY Matt (dir.), Keywords in Sound, Durham, Duke University Press, 2015, p. 12-21.

MOSLEY Imani Danielle, “Say Her Name: Invocation, Remembrance, and Gendered Trauma in Black Lives Matter", dans FAUSER Annegret et FIGUEROA Michael A. (dir.), Performing Commemoration. Musical Reenactment and the Politics of Trauma, Ann Arbor, University of Michigan Press, 2020, p. $142-161$.

RADANo Ronald et olANIYAN Tejumola (dir.), Audible Empire. Music, Global Politics, Critique, Durham, Duke University Press, 2016.

schWARz Bill, The White Man's World, Oxford et New York, Oxford University Press, 2011.

\section{NOTES}

1. The version published in 1999 benefited from thoughtful commentary by Tim Carter, Katharine Ellis, Mark Everist, and Joël-Marie Fauquet, to whom I am still immensely grateful.

2. The term "acoustemology", coined by Steven Feld, concerns "the experience and agency of listening histories, understood as relational and contingent, situated and reflexive". See FELD, Steven, "Acoustemology", NovAK David and SAKAKEENY Matt (ed.), Keywords in Sound, Durham, Duke University Press, 2015, p. 12-21.

3. Bellaigue, « Revue musicale » (Esclarmonde), p. 699.

4. The literature on gender, ethnicity and imperialism is vast, regarding not only France but also (and especially, perhaps) the British Empire. See, for example, SchwARz, Bill, The White Man's World, Oxford and New York, Oxford University Press, 2011. For an exploration of the intersection 
of music with 'race' and Empire for more recent musical practices, see RADANO, Ronald and olaniyan, Tejumola (ed.), Audible Empire. Music, Global Politics, Critique, Durham, Duke University Press, 2016.

5. Leslie C. Dunn and Nancy A. Jones offer one of the most concise definitions of vocality in relation to human expression: "Human vocality encompasses all the voice's manifestations (for example, speaking, singing, crying, and laughing), each of which is invested with social meanings not wholly determined by linguistic content". They identify a slippage between feminine vocality and sexuality by means of "the identification of a woman's vocality with her sexuality". See Dunn, Leslie C. and Jones, Nancy A. (ed.), Embodied Voices. Representing Female Vocality in Western Culture, Cambridge and New York, Cambridge University Press, 1994, p. 1 and 3. On vocality and its extrinsic referents, see also EIDSHEIM, Nina Sun, The Race of Sound. Listening, Timbre, and Vocality in African American Music, Durham, Duke University Press, 2019.

6. For a discussion of this problematic connection in late nineteenth-century opera, see BOGHAL, Gurminder Kaur, “Lakmé’s Echoing Jewels", CowGILL, Rachel and PoRISs, Hilary (ed.), The Arts of the Prima Donna in the Long Nineteenth Century, New York, Oxford University Press, 2012, p. 186-201.

7. See the poignant discussion of this subject by MosLEY, Imani Danielle, "Say Her Name: Invocation, Remembrance, and Gendered Trauma in Black Lives Matter", FAUSER, Annegret and FIGUEROA, Michael A. (ed.), Performing Commemoration. Musical Reenactment and the Politics of Trauma, Ann Arbor, University of Michigan Press, 2020, p. 142-161.

\section{AUTHOR}

\section{ANNEGRET FAUSER}

Annegret Fauser is Cary C. Boshamer Distinguished Professor of Music at the University of North Carolina in Chapel Hill. Her research focuses on music of the nineteenth and twentieth centuries, especially that of France and the United States. She is the author of Musical Encounters at the 1889 Paris World's Fair (2005), Sounds of War: Music in the United States during World War II (2013), The Politics of Musical Identity (2015), and Aaron Copland's "Appalachian Spring" (2017). She was awarded the 2011 Edward J. Dent Medal of the Royal Musical Association, and from 2011 to 2013 served as the Editor-in-Chief of the Journal of the American Musicological Society. In October 2020, Performing Commemoration: Musical Reenactment and the Politics of Trauma (co-edited with Michael A. Figueroa), was published in the Music and Social Justice series of University of Michigan Press. 